\title{
Skeletal and dental characteristics in subjects with ankyloglossia
}

\author{
Bhadrinath Srinivasan ${ }^{*}$ and Arun B Chitharanjan
}

\begin{abstract}
Background: The role of ankyloglossia in etiology of malocclusion is not much discussed over the years. The aim of the present study was to assess the skeletal and dental characteristics in subjects with ankyloglossia.

Methods: Fifty-seven subjects diagnosed with ankyloglossia (group 1) were compared with 60 subjects (group 2) without ankyloglossia, who had class I skeletal base. Ankyloglossia was diagnosed and graded (mild, moderate, severe and very severe) using Kortlow's method. SNA, SNB, ANB, Go-Gn-SN angle, FMA, maxillary and mandibular intercanine widths and intermolar widths, tooth size-arch length discrepancy in maxillary and mandibular arches and overbite were measured. Independent $t$ test was used to compare the mean parameters between the two groups. Analysis of variance and Tukey honestly significant difference were used to compare mean parameters among various grades of ankyloglossia.
\end{abstract}

Results: Majority of group 1 subjects belonged to class I skeletal base followed by class II and class III skeletal bases. Moderate ankyloglossia was most common in group 1. The mean maxillary and mandibular intercanine widths and maxillary intermolar width were statistically significant in independent $t$ test $(P<0.01)$ and reduced in group 1. In ANOVA followed by Tukey HS, the Go-Gn-SN angle and overbite were statistically significant among different grades of ankyloglossia $(P<0.05)$.

Conclusions: Subjects with ankyloglossia had reduced maxillary and mandibular intercanine widths and reduced maxillary intermolar width. The mandibular plane angle and overbite were altered with severity of ankyloglossia.

\section{Background}

Frenum is a fold of tissue inside the oral cavity which connects structures like the lip, tongue and buccal musculature to the alveolar bone. The frenums in the oral cavity include the maxillary midline frenum, mandibular midline frenum, the right and left upper and lower buccal frenums and the lingual frenum. The primary function of the frenum is to keep a balance between the growing bones, the tongue and the lip musculature during the development of the foetus and limit the movement of the muscular tissues like the lip, tongue and cheeks [1]. Abnormal frenal attachment may affect the movement of the above-mentioned structures, which in turn may have an effect on the position of jaws and arrangement of dentition.

More frequently discussed frenal anomaly in the literature is thick fibrous labial frenum, which causes maxillary

\footnotetext{
* Correspondence: bhadrinathsrini@gmail.com

Department of Orthodontics, Sri Ramachandra University, Porur, Chennai 600116, India
}

midline diastema. Abnormal attachment of lingual frenum, called as ankyloglossia, is a congenital anomaly characterized by short lingual frenum (Figure 1). Ankyloglossia, commonly known as tongue tie, has a prevalence of $4.2 \%$ to $10.7 \%$ in the population [2]. There is a mild male predilection with a ratio 1.5:1 [3,4]. Genetic role in the etiology of the ankyloglossia has been discussed by [5], who proposed the possible involvement of human G-protein coupled receptor gene (Lgr5). Ankyloglossia is also inherited as a familial condition either isolated or associated with other anomalies like X-linked cleft palate mutation of gene encoding transcription factor TBX22 [5], Kindler's syndrome [6] and Vander Woude syndrome [7]. It is inherited as an autosomal dominant condition with male to male transmission. The tongue exerts an outward pressure on the teeth, which is counteracted by the constricting effect of the buccal musculature. Equilibrium between these two groups of musculature is necessary for maintenance of arch widths [8]. Hence, altered position of the tongue can also affect the position of the mandible [9]. Ankyloglossia

\section{黑 Springer}




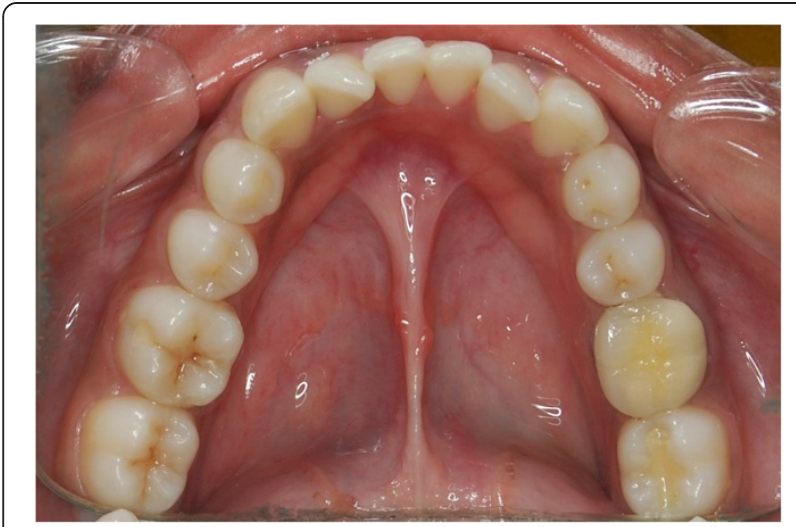

Figure 1 Ankyloglossia.

with varying degrees of restricted tongue mobility can cause feeding difficulties during infancy and speech problems and can affect the position of the mandible and the alignment of teeth leading to malocclusion. Due to the restricted mobility, the tongue cannot be lifted upward and subsequently may lead to tongue thrust and open bite [1]. The purpose of the study was to assess certain skeletal and dental characteristics seen in subjects with ankyloglossia and discuss the role of ankyloglossia in etiology of certain malocclusion.

\section{Methods}

This is a case-control study. The study included two groups (groups 1 and 2). Group 1 included 57 subjects diagnosed with ankyloglossia, from patients referred to the Department of Orthodontics, Faculty of Dental Sciences, Sri Ramachandra University, Chennai, India for orthodontic treatment. The sample size was calculated based on the formula which calculates the sample based on the prevalence of the condition.

$$
N=t^{2} p(1-p) / m^{2}
$$

where $N$ is the sample size, $t$ is the confidence interval at $95 \%$ (standard value 1.96) and $m$ is the margin of error at $5 \%$ level (standard value 0.05).

The diagnosis of ankyloglossia was based on visual inspection and the criteria put forward by [10]. The mean age was 19.02 years. Subjects with only permanent dentition and without any history of previous orthodontic treatment were included in the study. Subjects in primary dentition and mixed dentition and subjects with neuromuscular problems and severe skeletal problems with asymmetry were excluded from the study. Subjects with missing teeth other than third molars were also excluded from the study. The group 2 which comprised controls had 60 subjects selected consecutively from patients, who reported to the department for orthodontic treatment and had class I skeletal base with malocclusion. The principle behind including subjects with malocclusion in group 2 was to find out whether ankylglossia can be attributed exclusively to changes in the parameters in group 1, as parameters such as crowding, open bite and arch constriction can even occur without ankyloglossia. The criteria for class I skeletal base was based on ANB angle $2^{\circ} \pm 2^{\circ}$ [11]. The inclusion criteria and exclusion criteria for the control group was the same as that of the experimental group. The proposal was approved by the Institutional Ethical Committee of Sri Ramachandra University. An informed consent was obtained from the subjects participating in the study.

\section{Measurement of ankyloglossia}

The measurement of ankyloglossia was based on the classification and grading system given by [10]. It was done using a digital vernier calliper which could make a minimum measurement of $0.01 \mathrm{~mm}$. The distance between the tip of the tongue and the point of attachment of the lingual frenum was measured in millimetres (Figure 2). Clinically acceptable normal range for free tongue is $16 \mathrm{~mm}$. The various grades of ankyloglossia are as follows:

- Class I: mild ankyloglossia (12 to $16 \mathrm{~mm}$ )

- Class II: moderate ankyloglossia (7 to $12 \mathrm{~mm}$ )

- Class III: severe ankyloglossia (3 to $7 \mathrm{~mm}$ )

- Class IV: complete ankyloglossia $(<3 \mathrm{~mm})$

As the tongue is a more flexible organ, a dental instrument is placed at the base of the tongue where the frenum gets attached to the tongue for stabilization. Each measurement was done by the principal investigator. The dental characteristics were measured using study models prepared as part of the diagnostic record. The dental characteristics recorded include maxillary intercanine and intermolar widths, mandibular intercanine and intermolar widths, maxillary and mandibular tooth size-arch length discrepancy and overbite. The

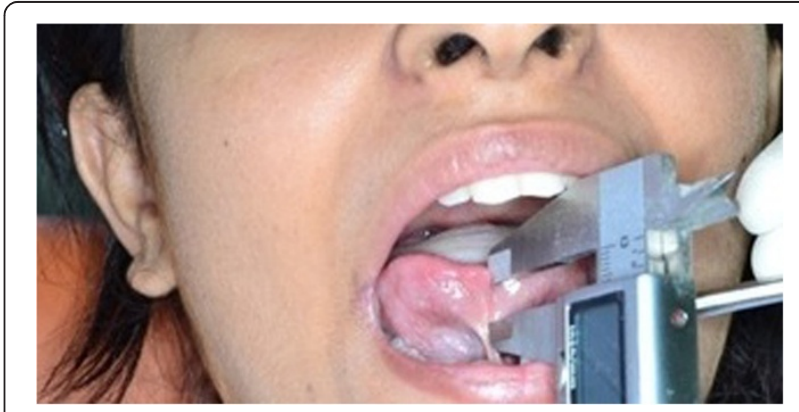

Figure 2 Measurement of ankyloglossia with digital calliper. 
measurements were made with the same digital vernier calliper. The maxillary and the mandibular intercanine widths are measured as the distance in millimetres between the cusp tips of the right and the left canine [12]. Maxillary intermolar width was measured as the distance between the mesial fossa of the right and left maxillary first permanent molars, and the mandibular intermolar width was measured as the distance between the central fossa of the right and left mandibular permanent first molars [12]. Maxillary and mandibular tooth size-arch length discrepancy (TSALD) is measured using arch perimeter and Carey's analysis [13]. The overbite was measured using a metal ruler.

\section{Skeletal measurements}

Skeletal measurements were done using a lateral cephalogram. Lateral cephalograms were traced using a 0.03in. acetate paper. Parameters such as SNA, SNB, ANB, GoGn-SN angle from Steiner's analysis [11] and Frankforts mandibular plane angle [14] were recorded. According to the ANB value, the skeletal base was categorized into class $\mathrm{I}\left(\mathrm{ANB} \pm 2^{\circ}\right.$, class II $\left(\mathrm{ANB}>4^{\circ}\right)$ and class III $\left(\mathrm{ANB}<0^{\circ}\right)$.

All the linear and angular measurements were repeated for 14 days by the principal investigator. The method error of measurements was calculated using Dahlberg's formula [15]:

$$
\text { Method error }=\sqrt{ } \sum \mathrm{d}^{2} / 2 \mathrm{n}
$$

where $d$ is the difference between two measurements made from the same parameter and $n$ is the number of subjects.

The error of measurement for ankyloglossia was $0.22 \mathrm{~mm}$. The linear measurements ranged from 0.12 to $0.34 \mathrm{~mm}$ and from $0.34^{\circ}$ to $0.41^{\circ}$ for angular measurements.

The various parameters were statistically analysed using SPSS software. Independent $t$ test was used to compare the means in both group 1 and group 2 . ANOVA followed by Tukey honestly significant difference were done to compare the means among the various grades of ankyloglossia.

\section{Results}

\section{Measurements of ankyloglossia}

The mean ankyloglossia measurement was $8.32 \mathrm{~mm}$ in group 1 and $19.17 \mathrm{~mm}$ in group 2 (Table 1 ). In group 1 ,

Table 1 Measurements of ankyloglossia

\begin{tabular}{|c|c|c|c|}
\hline \multirow[t]{2}{*}{ Groups } & \multicolumn{2}{|c|}{ Sex (\%) } & \multirow{2}{*}{$\begin{array}{l}\text { Mean measurement } \\
\text { on the tongue }(\mathrm{mm}\end{array}$} \\
\hline & Male & $\overline{\text { Female }}$ & \\
\hline 1 & 59.65 & 40.35 & 8.32 \\
\hline 2 & 53.33 & 46.66 & 19.17 \\
\hline
\end{tabular}

$59.6 \%$ were males and $40.4 \%$ were females, showing a slight male predilection (male to female ratio 1.5:1). In group 1, 37 (64.91\%) patients had moderate ankyloglossia, $12(21.05 \%)$ patients had mild ankyloglossia and only $8(14.03 \%)$ subjects had severe ankyloglossia (Table 2). There was not a single subject with very severe ankyloglossia.

\section{Measurements in lateral cephalogram}

In group $1,70.16 \%$ of the subjects belonged to class I skeletal base, $26.31 \%$ of the subjects belonged to class II skeletal base and 3.5\% belonged to class III skeletal base. In independent $t$ test, none of the cephalometric parameters were statistically significant (Table 3). ANOVA (Table 4) showed that none of the parameters were statistically significant except Go-Gn-SN angle $(P=0.047)$ and overbite $(P=0.001)$. In the post hoc test (Table 5$)$, GoGn-SN angle was statistically significant $(P=0.038)$ between moderate (class II) and severe ankyloglossia (class III). The mean Go-Gn-SN angle in mild ankyloglossia $\left(32.38^{\circ} \pm 3.114^{\circ}\right)$ was greater than the mean angle in severe ankyloglossia $\left(28.75^{\circ} \pm 4.634^{\circ}\right)$.

\section{Measurements on dental casts}

In independent $t$ test (Table 6), the statistically significant variables were mean maxillary intercanine width (33.005 $\pm 3.269 \mathrm{~mm}, P=0.000)$, mean mandibular intercanine width $(26.584 \pm 2.363 \mathrm{~mm}, P=0.005)$, mean maxillary intermolar width $(42.8074 \pm 2.50223 \mathrm{~mm}, P=0.000)$ and maxillary tooth size-arch length discrepancy (3.60 \pm $3.2 .983 \mathrm{~mm}, P=0.005)$. The mean maxillary and mandibular intercanine widths and the maxillary intermolar width in group 1 were lesser in magnitude when compared to group 2.

In ANOVA, there was no statistical significance in the measurements made on the dental casts except for overbite $(P=0.001$, Table 7$)$. In the post hoc test (Table 8$)$, mean overbite was statistically significant between mild and severe ankyloglossia $(P=0.001)$ and also between moderate and severe ankyloglossia $(P=0.016)$. The mean overbite was reduced in mild $(2.13 \pm 1.642 \mathrm{~mm})$ ankyloglossia, and it was increased in severe $(4.67 \pm 1.435 \mathrm{~mm})$ ankyloglossia.

\section{Discussion}

According to Melvin Moss, the growth of soft tissues has a strong influence over the growth of hard tissues [16]. The tongue is also a soft tissue component which can affect the growth of the maxilla and mandible [9].

Table $\mathbf{2}$ Grade of ankyloglossia
\begin{tabular}{lrr}
\hline Mild & Moderate & Severe \\
\hline $12(21.05 \%)$ & $37(64.91 \%)$ & $8(14.03 \%)$ \\
\hline Number of subjects in group 1 and percentage.
\end{tabular}


Table 3 Independent $\boldsymbol{t}$ test for intergroup comparison of means between group 1 and group 2

\begin{tabular}{lcccc}
\hline Parameters (deg) & Groups & Mean & Standard deviation & $\boldsymbol{P}$ value \\
\hline Go-Gn-SN angle & 1 & 31.84 & 4.225 & 0.372 \\
& 2 & 31.08 & 3.758 & \\
FMA & 1 & 26.75 & 4.563 & 0.200 \\
& 2 & 25.74 & 3.070 & \\
\hline
\end{tabular}

The equilibrium between the tongue and buccinator muscle is responsible for the development of normal arch width of the maxillary and mandibular arches [8]. The size, position, structure and function of the tongue also have a potential role in the etiology of malocclusion. Tongue tie or ankyloglossia, which significantly affects the function of the tongue, in turn influences the development of the maxilla and mandible and also the arrangement of teeth. Most of the studies on ankyloglossia were mainly about feeding and speech difficulties in children.

This study used Kortlow's classification of ankyloglossia to diagnose and grade ankyloglossia. Many methods had been put forward to assess tongue tie [10,17-22]. Most of the above-mentioned methods involved more than one measurement and were too cumbersome. Kotlow's classification was used in this study, as it was very simple, involved only one measurement and easy to perform. This method used a calliper to measure the distance between the point of attachment of the frenum on the ventral surface of the tongue and the tip of the tongue.

Results in this study showed that ankyloglossia was more common in males compared to females (male/ female ratio $1.5: 1$ ) (Table 1 ). This was similar to the findings by $[3,4,19]$. The results depicted that moderate ankyloglossia was more common than mild and severe ankyloglossia (Table 2). There was no case of very severe ankyloglossia in the study sample, as the mean age in this group included in this study is 19.02 years and a case of a very severe ankyloglossia would have been diagnosed early in childhood and

Table 4 ANOVA for comparison of means of parameters among the different grades of ankyloglossia

\begin{tabular}{llccc}
\hline Parameters (deg) & $\begin{array}{l}\text { Grades of } \\
\text { ankyloglossia }\end{array}$ & Mean & $\begin{array}{l}\text { Standard } \\
\text { deviation }\end{array}$ & P value \\
\hline Go-Gn-SN angle & Grade 1 & 32.38 & 3.114 & $0.047^{\text {a }}$ \\
& Grade 2 & 32.73 & 5.042 & \\
& Grade 3 & 28.75 & 4.634 & \\
FMA & Grade 1 & 26.13 & 3.399 & 0.142 \\
& Grade 2 & 27.51 & 4.181 & \\
& Grade 3 & 24.83 & 4.345 & \\
\hline
\end{tabular}

${ }^{a}$ The mean difference is significant at the 0.05 level.
Table 5 Tukey HSD for comparison of means among the different grades of ankyloglossia individually

\begin{tabular}{llll}
\hline $\begin{array}{l}\text { Parameters } \\
\text { (deg) }\end{array}$ & $\begin{array}{l}\text { Grades of } \\
\text { ankyloglossia }\end{array}$ & $\begin{array}{l}\text { Intergroup comparison } \\
\text { between grades of } \\
\text { ankyloglossia }\end{array}$ & Significance \\
\hline $\begin{array}{l}\text { Go-Gn-SN } \\
\text { angle }\end{array}$ & Grade 1 & Grade 2 & 0.980 \\
& Grade 2 & Grade 3 & 0.225 \\
& & Grade 1 3 & 0.980 \\
& Grade 3 & Grade 1 & $0.038^{\mathrm{a}}$ \\
& & Grade 2 & 0.225 \\
FMA & Grade 1 & Grade 2 & $0.038^{\mathrm{a}}$ \\
& & Grade 3 & 0.665 \\
& Grade 2 & Grade 1 & 0.772 \\
& & Grade 3 & 0.665 \\
& Grade3 & Grade 1 & 0.133 \\
& & Grade 3 & 0.772 \\
& & 0.133 \\
\hline
\end{tabular}

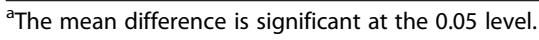

surgical correction would have been performed because of the feeding and speech difficulties imposed by it. Only some authors had worked on the relationship between malocclusion and ankyloglossia. In this study, majority of group 1 subject belonged to class I skeletal base followed by class II and class III skeletal bases, respectively (Table 9). This was contradictory to other authors [23-25] who reported that ankyloglossia was more common in class III skeletal malocclusion $[26,27]$ demonstrating no relation between the short lingual frenum and any dental or orthodontic anomalies. It

Table 6 Independent $\boldsymbol{t}$ test for intergroup comparison of means between groups 1 and 2

\begin{tabular}{lcccc}
\hline Parameters (mm) & Groups & Mean & $\begin{array}{c}\text { Standard } \\
\text { deviation }\end{array}$ & P value \\
\hline Maxillary intercanine width & 1 & 33.0084 & 3.983 & $0.000^{\mathrm{a}}$ \\
& 2 & 35.4022 & 2.937 & \\
Mandibular intercanine width & 1 & 26.5837 & 2.858 & $0.005^{\mathrm{a}}$ \\
& 2 & 27.9598 & 1.621 & \\
Maxillary intermolar width & 1 & 42.8074 & 4.938 & $0.000^{\mathrm{a}}$ \\
& 2 & 48.3738 & 4.200 & \\
Mandibular intermolar width & 1 & 39.8951 & 4.197 & 0.122 \\
Maxillary tooth size-arch & 2 & 41.0918 & 4.275 & \\
length discrepancy & 1 & 3.60 & 3.26950 & $0.010^{\mathrm{a}}$ \\
Mandibular tooth size-arch & 2 & 5.05 & 3.17573 & \\
length discrepancy & 1 & 3.49 & 2.36347 & 0.057 \\
Overbite & 2 & 4.40 & 2.74916 & \\
\hline
\end{tabular}

${ }^{a}$ The mean difference is significant at the 0.05 level. 
Table 7 ANOVA for comparison of means of parameters among different grades of ankyloglossia

\begin{tabular}{|c|c|c|c|c|}
\hline Parameters (mm) & $\begin{array}{l}\text { Grades of } \\
\text { ankyloglossia }\end{array}$ & Mean & $\begin{array}{l}\text { Standard } \\
\text { deviation }\end{array}$ & $P$ value \\
\hline \multirow{3}{*}{$\begin{array}{l}\text { Maxillary intercanine } \\
\text { width }\end{array}$} & Grade 1 & 34.6013 & 3.09882 & \multirow[t]{3}{*}{0.324} \\
\hline & Grade 2 & 32.6724 & 3.01512 & \\
\hline & Grade 3 & 32.9825 & 4.04118 & \\
\hline \multirow{3}{*}{$\begin{array}{l}\text { Mandibular intercanine } \\
\text { width }\end{array}$} & Grade 1 & 26.1613 & 2.29260 & \multirow[t]{3}{*}{0.624} \\
\hline & Grade 2 & 26.8103 & 2.26657 & \\
\hline & Grade 3 & 26.1667 & 2.79068 & \\
\hline \multirow{3}{*}{$\begin{array}{l}\text { Maxillary intermolar } \\
\text { width }\end{array}$} & Grade 1 & 43.2563 & 3.69900 & \multirow[t]{3}{*}{0.228} \\
\hline & Grade 2 & 43.0678 & 2.30516 & \\
\hline & Grade 3 & 41.7050 & 2.01913 & \\
\hline \multirow{3}{*}{$\begin{array}{l}\text { Mandibular intermolar } \\
\text { width }\end{array}$} & Grade 1 & 38.5275 & 3.92119 & \multirow[t]{3}{*}{0.422} \\
\hline & Grade 2 & 40.3730 & 3.98773 & \\
\hline & Grade 3 & 39.3333 & 3.79793 & \\
\hline \multirow{3}{*}{$\begin{array}{l}\text { Maxillary tooth size-arch } \\
\text { length discrepancy }\end{array}$} & Grade 1 & 1.88 & 4.155 & \multirow[t]{3}{*}{0.177} \\
\hline & Grade 2 & 3.57 & 3.637 & \\
\hline & Grade 3 & 4.83 & 1.899 & \\
\hline \multirow{3}{*}{$\begin{array}{l}\text { Maxillary tooth size-arch } \\
\text { length discrepancy }\end{array}$} & Grade 1 & 2.50 & 2.000 & \multirow[t]{3}{*}{0.481} \\
\hline & Grade 2 & 3.49 & 3.288 & \\
\hline & Grade 3 & 4.17 & 2.480 & \\
\hline \multirow[t]{3}{*}{ Overbite } & Grade 1 & 2.13 & 1.642 & \multirow[t]{3}{*}{$0.001^{a}$} \\
\hline & Grade 2 & 2.26 & 2.127 & \\
\hline & Grade 3 & 4.67 & 1.435 & \\
\hline
\end{tabular}

${ }^{\mathrm{a}}$ The mean difference is significant at the 0.05 level.

was hypothesized that protrusive chin in ankyloglossia may be due to low tongue posture, which causes the mandible to grow more forward $[9,22]$. However, in this study, only two subjects with ankyloglossia belonged to class III malocclusion. The reason could be that ankyloglossia may be an associative factor adding to the genetic component in the etiology of class III malocclusion rather than the sole etiologic factor. The mean Go-Gn-SN plane angle was greater and statistically significant in mild ankyloglossia when compared to severe ankyloglossia (Table 5) suggesting a more backward rotation of mandible. Although the mean Frankfurt mandibular plane angle was not statistically significant among the various grades of ankyloglossia, the value was greater in mild ankyloglossia than in severe ankyloglossia similar to Go-Gn-SN angle, indicating that the position of the tongue is altered in ankyloglossia which in turn can affect mandibular rotation (Table 5).

In this study, there was a significant reduction in maxillary intermolar width, maxillary intercanine width and mandibular intercanine width in group 1 when compared to group 2. However, there was no change in mandibular intermolar width (Table 6). The authors in [9] stated that ankyloglossia limits the upward movement of the tongue, thus preventing the formation of lip seal
Table 8 Tukey HSD for comparison of means among the different grades of ankyloglossia individually

\begin{tabular}{|c|c|c|c|}
\hline Parameters (mm) & $\begin{array}{l}\text { Grades of } \\
\text { ankyloglossia }\end{array}$ & $\begin{array}{l}\text { Intergroup comparison } \\
\text { between grades } \\
\text { of ankyloglossia }\end{array}$ & Significance \\
\hline \multirow{6}{*}{$\begin{array}{l}\text { Maxillary } \\
\text { intercanine } \\
\text { width }\end{array}$} & \multirow[t]{2}{*}{ Grade 1} & Grade 2 & 0.291 \\
\hline & & Grade 3 & 0.526 \\
\hline & \multirow[t]{2}{*}{ Grade 2} & Grade 1 & 0.291 \\
\hline & & Grade 3 & 0.956 \\
\hline & \multirow[t]{2}{*}{ Grade3 } & Grade 1 & 0.526 \\
\hline & & Grade 2 & 0.956 \\
\hline \multirow{6}{*}{$\begin{array}{l}\text { Mandibular } \\
\text { intercanine } \\
\text { width }\end{array}$} & \multirow[t]{2}{*}{ Grade 1} & Grade 2 & 0.766 \\
\hline & & Grade 3 & 1.000 \\
\hline & \multirow[t]{2}{*}{ Grade 2} & Grade 1 & 0.766 \\
\hline & & Grade 3 & 0.697 \\
\hline & \multirow[t]{2}{*}{ Grade 3} & Grade 1 & 1.000 \\
\hline & & Grade 2 & 0.697 \\
\hline \multirow{6}{*}{$\begin{array}{l}\text { Maxillary } \\
\text { intermolar width }\end{array}$} & \multirow[t]{2}{*}{ Grade 1} & Grade 2 & 0.979 \\
\hline & & Grade3 & 0.363 \\
\hline & \multirow[t]{2}{*}{ Grade 2} & Grade 1 & 0.979 \\
\hline & & Grade 3 & 0.232 \\
\hline & \multirow[t]{2}{*}{ Grade 3} & Grade 1 & 0.363 \\
\hline & & Grade 2 & 0.232 \\
\hline \multirow{6}{*}{$\begin{array}{l}\text { Mandibular } \\
\text { intermolar width }\end{array}$} & \multirow[t]{2}{*}{ Grade 1} & Grade 2 & 0.458 \\
\hline & & Grade 3 & 0.896 \\
\hline & \multirow[t]{2}{*}{ Grade 2} & Grade 1 & 0.458 \\
\hline & & Grade 3 & 0.708 \\
\hline & \multirow[t]{2}{*}{ Grade 3} & Grade 1 & 0.896 \\
\hline & & Grade 2 & 0.708 \\
\hline \multirow{6}{*}{$\begin{array}{l}\text { Maxillary tooth } \\
\text { size-arch length } \\
\text { discrepancy }\end{array}$} & \multirow[t]{2}{*}{ Grade 1} & Grade 2 & 0.421 \\
\hline & & Grade 3 & 0.152 \\
\hline & \multirow[t]{2}{*}{ Grade 2} & Grade 1 & 0.421 \\
\hline & & Grade 3 & 0.512 \\
\hline & \multirow[t]{2}{*}{ Grade 3} & Grade 1 & 0.152 \\
\hline & & Grade 2 & 0.512 \\
\hline \multirow{6}{*}{$\begin{array}{l}\text { Mandibular } \\
\text { tooth size-arch } \\
\text { length } \\
\text { discrepancy }\end{array}$} & \multirow[t]{2}{*}{ Grade 1} & Grade 2 & 0.677 \\
\hline & & Grade 3 & 0.448 \\
\hline & \multirow[t]{2}{*}{ Grade 2} & Grade 1 & 0.677 \\
\hline & & Grade 3 & 0.774 \\
\hline & \multirow[t]{2}{*}{ Grade 3} & Grade 1 & 0.448 \\
\hline & & Grade 2 & 0.774 \\
\hline \multirow[t]{6}{*}{ Overbite } & \multirow[t]{2}{*}{ Grade 1} & Grade 2 & 0.984 \\
\hline & & Grade 3 & $0.016^{a}$ \\
\hline & Grade 2 & Grade 1 & 0.984 \\
\hline & & Grade 3 & $0.001^{a}$ \\
\hline & Grade 3 & Grade 1 & $0.016^{\mathrm{a}}$ \\
\hline & & Grade 2 & $0.001^{\mathrm{a}}$ \\
\hline
\end{tabular}

${ }^{a}$ The mean difference is significant at the 0.05 level. 
Table 9 Measurements on lateral cephalogram

\begin{tabular}{ccc}
\hline \multicolumn{3}{c}{ Skeletal base } \\
\hline Class I & Class II & Class III \\
$40(70.16 \%)$ & $15(26.31 \%)$ & $2(3.5 \%)$ \\
\hline
\end{tabular}

Number of subjects in group 1 and percentage.

during swallowing, leading to tongue thrusting, which in turn can cause open bite. Also, the upward movement of the tongue is necessary for the creation of normal width of the hard palate. Inability of the tongue to lift upward results in unrestricted buccinator muscle activity, resulting in constriction of maxillary arch, which could be the reason for reduction in maxillary intermolar width and intercanine width in group 1. Reduction of mandibular intercanine width can be due to pull of the short lingual frenum resulting in constriction of mandibular anterior region. There was no significant difference in maxillary and mandibular intermolar widths and maxillary and mandibular intercanine widths between mild, moderate and severe ankyloglossia.

TSALD in maxillary and mandibular arches was present in both group 1 and group 2 and was statistically significant in the maxillary arch (Table 6). The mandibular and maxillary anterior crowding could be due to arch constriction seen in maxillary and mandibular regions. However, the magnitude of mean TSALD was greater in group 2 when compared to group 1 . The reasons for increased TSALD in group 2 could be due to the severity of the malocclusions included in that group.

The overbite was not statistically significant in the independent $t$ test (Table 6), but in ANOVA, it was statistically significant among mild, moderate and severe ankyloglossia (Table 7). In post hoc comparison, the mean overbite was statistically significant between mild and severe ankyloglossia and moderate and severe ankyloglossia. The mean overbite was greatest in severe ankyloglossia and least in mild ankyloglossia (Table 8). The authors in [9] demonstrated that maxillary arch constriction, maxillary protrusion, crowding and open bite were more common in subjects with ankyloglossia compared to deep bite and spacing. Although the overbite was reduced in mild and moderate ankyloglossia, there was no open bite among those subjects. Though there was a statistical significance in the mean overbite values between mild and severe and moderate and severe ankyloglossia, the difference in the mean values was not greater for it to be clinically significant. This was contrary to the previous hypothesis that ankyloglossia can result in tongue thrust leading to open bite. This showed that restricted mobility of the tongue can cause tongue thrust but not severe enough to cause an open bite. Also, increased mandibular plane angle in mild ankyloglossia could be related to decreased overbite in them. Overbite reduction was not seen in severe ankyloglossia, because the restriction of mobility would be greater and hence less chance to develop a tongue thrust habit to decrease the overbite.

This study has highlighted that ankyloglossia could be related to maxillary arch constriction both in the anterior and posterior regions and constriction of arch in the mandibular anterior region. Ankyloglossia also affects the overbite and the mandibular plane angle. Hence, subjects with ankyloglossia can be considered for surgical correction before orthodontic treatment, as improper tongue function due to ankyloglossia can affect the facial growth and also the outcome of treatment [9].

There were certain limitations in this study. A better cause and effect relationship between ankyloglossia and malocclusion can be brought out with a longitudinal study or a twin study. Also, the present study did not consider the functional aspects of ankyloglossia as it was not under the preview of the study. The various movements of tongue like lateralization, lift, extension, spread, cupping and peristalsis movements should be recorded and related to the skeletal and dental changes in ankyloglossia for future research.

\section{Conclusions}

The present study investigated certain skeletal and dental characteristics in subjects with ankyloglossia. There was a slight male predilection in subjects with ankyloglossia. Moderate ankyloglossia was more common than mild and severe ankyloglossia. Ankyloglossia was more common in class I skeletal base followed by class II skeletal base and class III skeletal base. Maxillary intermolar width and maxillary intercanine width are significantly reduced in subjects with ankyloglossia suggesting maxillary constriction. Overbite and mandibular plane angle changed with the severity of ankyloglossia.

\section{Competing interests}

The authors declare that they have no competing interests.

\section{Authors' contributions}

BS participated in selecting the topic, designing the study, carrying out the measurements on the tongue, dental casts and lateral cephalogram, analysing the results and drafting the manuscript. $A B C$ participated in designing the study, analysing the results and drafting the manuscript. Both authors read and approved the final manuscript.

\section{Authors' information}

$\mathrm{BS}$ is a senior lecturer and $\mathrm{ABC}$ is a professor and head of the Department of Orthodontics, Sri Ramachandra University, Porur, Chennai 600116, India.

Received: 20 June 2013 Accepted: 24 October 2013

Published: 7 November 2013

\section{References}

1. Northcutt ME. The lingual frenum. J Clin Orthod. 2009; 43(9):557-65.

2. Segan LM, Stephenson S, Dawes M. Feldman. Prevalence, diagnosis, and treatment of ankyloglossia. Methodologic review. Can Fam Physician. 2007; 53:1027-33.

3. Ballard JL, Auer CE, Khoury JC. Ankyloglossia assessment, incidence and effect of frenuloplasty on the breastfeeding dyad. Pediatrics. 2002; 110:e63. 
4. Morowati S, Yasini M, Ranjbar R, Peivandi AA, Ghadami M. Familial ankyloglossia (tongue-tie): a case report. Acta Med Iran. 2010; 48(2):123-4.

5. Acevedo AC, da Fonseca JA, Grinham J, Doudney K, Gomes RR, de Paula $L M$, Stanier P. Autosomal-dominant ankyloglossia and tooth number anomalies. J Dent Res. 2010; 89(2):128-32.

6. Hacham-Zadeh S, Garfunkel AA, Opitz JM, Reynolds JF. Kindler syndrome in two related Kurdish families. Am J Med Genet. 1985; 20:43-8.

7. Burdick $A B, M a L A, D a i Z H$, Gao NN. Van der Woude syndrome in two families in China. J Craniofac Genet Dev Biol. 1987; 7:413-8.

8. Proffit WR. Equilibrium theory revisited: factors influencing position of the teeth. Angle Orthod. 1978; 48:175-86.

9. Defabianis P. Ankyloglossia and its influence on maxillary and mandibular development. (A seven year follow-up case report). Funct Orthod. 2000; 17:25-33.

10. Kotlow LA. Ankyloglossia (tongue-tie): a diagnostic and treatment quandary. Quintessence Intl. 1999; 30:259-62.

11. Steiner CC. Cephalometrics for you and me. Am J Orthod. 1953; 39 (10):729-55

12. Bishara SE, Jakobsen JR, Treder J, Nowak A. Arch width changes from 6 weeks to 45 years of age. Am J Orthod Dentofacl Orthop. 1997; 111(4):401-9.

13. Carey CW. Linear arch dimension and tooth size. Am J Orthod. 1949; 35:762-75.

14. Tweed $\mathrm{CH}$. The Frankfort mandibular plane angle in orthodontic diagnosis, classification, treatment planning and prognosis. Am J Orthod. 1946; 32:175-230.

15. Dahlberg G. Statistical methods for medical and biological students. New York: Interscience Publications; 1940

16. Moss $\mathrm{M}$. The primary role of functional matrices in facial growth. Am J Orthod. 1969; 55:566-77.

17. Fletcher SG, Meldrum JR. Lingual function and relative length of the lingual frenulum. I Speech Hear Res. 1968; 11:382-90

18. Hazelbaker AK. The Assessment Tool for Lingual Frenulum Function (ATLFF): use in a lactation consultant private practice, Master's thesis. Pasadena: Pacific Oaks College; 1993.

19. Messner AH, Lalakea ML. Ankyloglossia: controversies in management. Int J Pediatr Otorhinolaryngol. 2000; 54:123-31.

20. Marchesan IQ. Lingual frenulum: quantitative evaluation proposal. Int J Orofacial Myology. 2005; 31:39-48.

21. Ruffoli R, Giambelluca MA, Scavuzzo MC, Bonfigli D, Cristofani R, Gabriele M, Giuca MR, Giannessi F. Ankyloglossia: a morphofunctional investigation in children. Oral Dis. 2005; 11:170-4.

22. Jeong-Jang S, Cha B, Ngan P, Choi D, Lee S, Jang I. Relationship between the lingual frenulum and craniofacial morphology in adults. Am J Orthod Dentofac Orthop. 2011; 139:e361-7.

23. Whitman CL, Rankow RM. Diagnosis and management of ankyloglossia. Am J Orthod. 1961; 47:423-8.

24. Mukai S, Mukai C, Asaoka K. Congenital ankyloglossia with deviation of the epiglottis and larynx: symptoms and respiratory function in adults. Ann Otol Rhinol Laryngol. 1993; 102:620-4.

25. Tuerk M, Lubit EC. Ankyloglossia. Plast Reconstr Surg. 1959; 24:271-6.

26. Mazzocchi A, Clini F. Short lingual frenum: clinical and therapeutic considerations. La Pediatria medica e chirurgica. Pediatr Med Chi. 1992; 14:643-6.

27. Garcia Pola MJ, Gonzalez Garcia M, Garcia Martin JM, Gallas M, Leston SJ. A study of pathology associated with short lingual frenum. J Dent Child. 2002; 69:59-62.

doi:10.1186/2196-1042-14-44

Cite this article as: Srinivasan and Chitharanjan: Skeletal and dental characteristics in subjects with ankyloglossia. Progress in Orthodontics $201314: 44$.

\section{Submit your manuscript to a SpringerOpen ${ }^{\circ}$ journal and benefit from:}

- Convenient online submission

- Rigorous peer review

- Immediate publication on acceptance

- Open access: articles freely available online

- High visibility within the field

- Retaining the copyright to your article

Submit your next manuscript at $>$ springeropen.com 